Bangladesh J. Plant Taxon. 21(1): 83-91, 2014 (June)

(C) 2014 Bangladesh Association of Plant Taxonomists

\title{
DETERMINATION OF INFORMANT CONSENSUS FACTOR OF ETHNOMEDICINAL PLANTS USED IN KALENGA FOREST, BANGLADESH
}

\author{
Mohammad Zashim Uddin ${ }^{1}$ And Md. Abul Hassan \\ Department of Botany, University of Dhaka, Dhaka 1000, Bangladesh
}

Keywords: Determination; Medicinal uses; Consensus factor; Kalenga forest.

\begin{abstract}
The present article tried to document the ethnomedicinal uses of plants and determine the consensus factor among villagers of Kalenga forest area to evaluate the potential for new drugs of herbal origin. This study was conducted in 2010 using semistructured questionnaire with villagers engaged in the forest management. The present study documented 35 plant species under 25 families for treatment of 11 categories of ailments using 52 medicinal formularies in Kalenga forest area. There was great agreement among the informants regarding ethnomedicinal uses of plants with Factor of Informants Consensus (FIC) value ranging from 0.50 to 0.95 , with an average value of 0.73 . The study revealed that most of the informants agreed in the use of Litsea glutinosa (Lour.) Roxb. to treat dysentery (FIC 0.95) that showed the highest fidelity level (95.23\%). The results of the study also indicated that $L$. glutinosa might be used for the development of new, cheap, effective, and eco-friendly herbal formulations for healthcare management. Villager's views and our observations confirmed that L. glutinosa is a rare plant in the study area. Illegal and unsustainable collection of bark from this tree by the local crude drug traders considered as major causes of its depletion from nature.
\end{abstract}

\section{Introduction}

Studies on the ethnomedicinal uses of plants by the local people are often significant because it provides a gateway for the exploration of new drugs source from the herbal origin (Teklehaymanot and Giday, 2007). Right from its beginning, the documentation of traditional knowledge, especially on the medicinal uses of plants, has provided many important drugs of modern day (Balick and Cox, 1997; Flaster, 1996). According to WHO (2001), 80\% of the world population uses natural remedies and traditional medicines for their primary healthcare. Documentation of medicinal usages of plants in Bangladesh has already been started. Some noticeable studies include Hassan and Khan (1986,1996), Mia and Huq (1988), Khan et al. (2002), Uddin and Hassan (2004), Uddin et al. (2004, 2006, 2012), Uddin (2006) and Uddin et al. (2008). All such works have listed the medicinal plants of particular area or community with their medicinal uses and none of these studies considered any quantitative consensus technique or ethno-directed technique for the analysis of medicinal uses of plants. In ethno-directed technique, plants are collected, which are used as medicine by the local people living in a specific area, for phytochemical and pharmacological analysis. Cox and Balick (1994) and Cordell (2000) state that this method plays a fundamental role in biodiversity prospecting. Proper selection of important plant species is a prerequisite to begin ethno-pharmacological, phytochemical and toxicological studies because of huge laboratory cost (Canalesa et al., 2005). For this purpose, it is necessary to determine the species that are most used to treat a particular illness. A useful tool to find a particular species is the Informant Consensus Factor (Frei et al., 1998; Heinrich et al., 1998). So

${ }^{1}$ Corresponding author. Email: zashim07@yahoo.com 
the present study was designed to document the medicinal uses of plants and to determine consensus of such uses among the villagers of Kalenga forest area, in order to evaluate their potential for new drugs of herbal origin.

\section{Materials and Methods}

Kalenga forest area is located in the eastern part of Chunarughat Upazila of Habiganj district adjacent to the border of Tripura State of India and nearly $130 \mathrm{~km}$ northeast of Dhaka and approximately $80 \mathrm{~km}$ southwest of Sylhet city. The study area has been described in detail by Uddin et al. (2002).

The study area was visited four times in different seasons of the year of 2010. Voucher specimens for each species have been collected and processed using standard herbarium techniques (Hyland, 1972; Alexiades, 1996). The specimens were identified consulting different Floras, viz., Hooker (1872-1897), Prain (1903), Uddin and Hassan (2004), Siddiqui et al. (2007) and Ahmed et al. (2008a, 2009a,b). Plant specimens available at Dhaka University Salar Khan Herbarium (DUSH) and Bangladesh National Herbarium (DACB) have also been consulted for confirmation of identified species. The updated nomenclature of the identified species followed Siddiqui et al. (2007) and Ahmed et al. (2008a,b, 2009a,b,c,d). Voucher specimens are deposited at DUSH.

Ethnomedicinal data has been collected through Participatory Rural Appraisal (PRA), which is based on interaction with indigenous people and direct observation in the field (Chambers, 1994; Martin, 1995). The data have been recorded through semi-structured interviews with villagers engaged in the forest management (Alexiades, 1996). A total of 42 people have been interviewed who are involved in forest management system. Once, these villagers lived inside the forest. After the declaration of Kalenga as a reserved forest they were evacuated from the forest and later forest department resettled them near their office with an agreement between forest department and villagers. They have to stay near forest office and protect forest in exchange of using marginal forest land for agriculture. During the field survey, information on uses of plants to treat different illnesses of human being, parts used, modes of preparation and administration of medicine have been collected. Based on the information obtained from the informants in the study area, all the reported ailments have been grouped into 11 categories.

The level of homogeneity among information provided by different informants was calculated by the Informants' Consensus Factor, FIC (Trotter and Logan, 1986) using the following formula:

FIC $=$ Nur - Nt $/($ Nur -1$)$

Where, Nur $=$ number of use reports from informants for a particular plant-use category; $\mathrm{Nt}=$ number of taxa or species that are used for that plant use category for all informants.

FIC Values range between 0 and 1, where ' 1 ' indicates the highest level of informant consent.

The fidelity level (FL), the percentage of informants claiming the use of a certain plant species for the same major purpose, was calculated for the most frequently reported diseases or ailments as:

FL $(\%)=(\mathrm{Np} / \mathrm{N}) \times 100$

Where, $\mathrm{Np}=$ number of informants that claim a use of a plant species to treat a particular disease; $\mathrm{N}=$ number of informants that use the plants as a medicine to treat any given disease (Alexiades, 1996).

\section{Results and Discussion}

In the present study 35 plant species under 25 families in Kalenga forest area have been documented for treatment of 11 categories of ailments through 52 medicinal formularies. Out of 52 formularies, 45 were of oral application and rest 7 of external applications. Among the 
recorded taxa, herbs are represented by 16 species followed by trees (13) and shrubs (6). For each species botanical name, family, voucher number, local name, ailments to be treated, mode of administration, and part(s) used were recorded (Table1). Use of plant parts as medicine among the informants shows variations. Leaves are mostly used part for majority of the medicinal plants, followed by fruits, bark, stem, petiole, whole plant and root (Table 1). Similar trend of harvesting leaves for medicinal use has also been reported from Lawachara National Park (Uddin et al., 2012). In the present study area threat to the species is minimal as leaves are the leading plant part used for medicinal purposes. It was observed that the collection of bark as medicinal part from the wild were not sustainable. According to local people, this type of activity is carried out by the collectors related to illegal trade of medicinal plants. Litsea glutinosa is vulnerable to this kind of activity in the study area.

Table 1. Documentation of medicinal plants with scientific name, vernacular name, parts used, ailments and mode of administration

\begin{tabular}{|c|c|c|c|c|}
\hline $\begin{array}{l}\text { Botanical name/family/ } \\
\text { voucher number }\end{array}$ & $\begin{array}{l}\text { Vernacular } \\
\text { name }\end{array}$ & $\begin{array}{l}\text { Parts } \\
\text { used }\end{array}$ & Ailments & Mode of administration \\
\hline $\begin{array}{l}\text { Averrhoa carambola L. } \\
\text { Averrhoaceae, Z- } 154\end{array}$ & Kamranga & Fruits & Jaundice & Ripe fruits taken internally \\
\hline $\begin{array}{l}\text { Azadirachta indica A. Juss. } \\
\text { Meliaceae, Z- } 1097\end{array}$ & Neem & Leaves & Allargy & $\begin{array}{l}\text { Small tablets are made from } \\
\text { leaf paste and taken } \\
\text { internally }\end{array}$ \\
\hline \multirow{2}{*}{$\begin{array}{l}\text { Bulbophyllum lilacinum Ridl. } \\
\text { Orchidaceae, Z- } 638\end{array}$} & Ishwarmul & Petiole & Diabetes & Petiole juice taken internally \\
\hline & & & Gastrict pain & Petiole juice taken internally \\
\hline $\begin{array}{l}\text { Cajanus cajan (L.) Millsp. } \\
\text { Fabaceae, Z- } 1133\end{array}$ & Orhor & Leaves & Jaundice & Leaf juice taken internally \\
\hline $\begin{array}{l}\text { Centella asiatica (L.) Urban } \\
\text { Apiaceae, Z- } 1112\end{array}$ & Tunimankuni & $\begin{array}{l}\text { Whole } \\
\text { plant }\end{array}$ & Dysentry & $\begin{array}{l}\text { Whole plant is taken as juice } \\
\text { or paste internally }\end{array}$ \\
\hline $\begin{array}{l}\text { Ceriscoides campanulata } \\
\text { (Roxb.) Tirven, Rubiaceaen } \\
\text { Z-1045 }\end{array}$ & Behlom & Fruits & Jaundice & $\begin{array}{l}\text { Fruits used in curry and } \\
\text { taken internally }\end{array}$ \\
\hline $\begin{array}{l}\text { Chromolaena odorata (L.) } \\
\text { King and Rob., Asteraceae } \\
\text { Z-140 }\end{array}$ & Pissais & Leaves & $\begin{array}{l}\text { Cut and } \\
\text { wound }\end{array}$ & $\begin{array}{l}\text { Leaf paste applied } \\
\text { externally }\end{array}$ \\
\hline \multirow[t]{2}{*}{$\begin{array}{l}\text { Clerodendrum viscosum } \\
\text { Vent., Verbenaceae, Z- } 220\end{array}$} & Bhat & Leaves & $\begin{array}{l}\text { Fever and } \\
\text { Malaria }\end{array}$ & Leaf juice taken internally \\
\hline & & & $\begin{array}{l}\text { Anti- } \\
\text { helminthes }\end{array}$ & Leaf juice taken internally \\
\hline $\begin{array}{l}\text { Cuscuta reflexa Roxb. } \\
\text { Cuscutaceae, Z- } 464\end{array}$ & Sharnalata & Stem & Diarrhoea & Stem juice taken internally \\
\hline $\begin{array}{l}\text { Dalbergia sissoo Roxb. } \\
\text { Fabaceae, Z- } 190\end{array}$ & Shishu & Leaves & Dysentery & Leaf juice taken internally \\
\hline $\begin{array}{l}\text { Datura metel L. } \\
\text { Solanaceae, Z- } 183\end{array}$ & Dutra & Leaves & Allergy & Leaf juice applied externally \\
\hline $\begin{array}{l}\text { Dillenia indica L. } \\
\text { Dilleniaceae, Z- } 991\end{array}$ & Chailta & Fruits & Jaundice & Ripe fruits taken internally \\
\hline
\end{tabular}


Table 1 Contd.)

\begin{tabular}{|c|c|c|c|c|}
\hline $\begin{array}{l}\text { Dillenia pentagyna Roxb. } \\
\text { Dilleniaceae, Z- } 755\end{array}$ & Harganja & Bark & $\begin{array}{l}\text { Cut and } \\
\text { wound }\end{array}$ & Inner bark applied externally \\
\hline $\begin{array}{l}\text { Eclipta alba (L.) Hassk. } \\
\text { Asteraceae, Z- } 1135\end{array}$ & Kaissa & $\begin{array}{l}\text { Whole } \\
\text { plant }\end{array}$ & Gastrict pain & $\begin{array}{l}\text { Whole plant juice taken } \\
\text { internally }\end{array}$ \\
\hline \multirow[t]{2}{*}{$\begin{array}{l}\text { Glycosmis pentaphylla (Retz.) } \\
\text { A. DC., Rutaceae, Z- } 323\end{array}$} & Hotigira & Leaves & $\begin{array}{l}\text { Cut and } \\
\text { wound }\end{array}$ & $\begin{array}{l}\text { Leaf paste applied } \\
\text { externally }\end{array}$ \\
\hline & & & Jaundice & Leaf juice taken internally \\
\hline \multirow[t]{4}{*}{$\begin{array}{l}\text { Justicia adhatoda L. } \\
\text { Acanthaceae, Z- } 152\end{array}$} & Bashak & Leaves & $\begin{array}{l}\text { Cold and } \\
\text { cough }\end{array}$ & Leaf juice taken internally \\
\hline & & & $\begin{array}{l}\text { Fever and } \\
\text { Malaria }\end{array}$ & Leaf juice taken internally \\
\hline & & & Impotence & Leaf juice taken internally \\
\hline & & & Jaundice & Leaf juice taken internally \\
\hline $\begin{array}{l}\text { Justicia gendarussa Burm. f. } \\
\text { Acanthaceae, Z- } 1067\end{array}$ & Kalobashak & Leaves & $\begin{array}{l}\text { Fever and } \\
\text { Malaria }\end{array}$ & Leaf juice taken internally \\
\hline \multirow{2}{*}{$\begin{array}{l}\text { Leucas aspera (Willd.) Link. } \\
\text { Lamiaceae, Z- } 1101\end{array}$} & Dolonshak & Leaves & Allergy & Fried leaf taken internally \\
\hline & & & $\begin{array}{l}\text { Cold and } \\
\text { cough }\end{array}$ & Fried leaf taken internally \\
\hline \multirow[t]{2}{*}{$\begin{array}{l}\text { Litsea glutinosa (Lour.) Roxb. } \\
\text { Lauraceae, Z- } 31\end{array}$} & Menda & $\begin{array}{l}\text { Bark, } \\
\text { Leaves }\end{array}$ & Dysentery & $\begin{array}{l}\text { Juice of both leaf and bark } \\
\text { taken internally }\end{array}$ \\
\hline & & & Jaundice & $\begin{array}{l}\text { Juice of both leaf and bark } \\
\text { taken internally }\end{array}$ \\
\hline $\begin{array}{l}\text { Melocana baccifera (Roxb.) } \\
\text { Kurz, Poaceae, Z-911 }\end{array}$ & $\begin{array}{l}\text { Mulibans } \\
\text { surface }\end{array}$ & $\begin{array}{l}\text { Stem } \\
\text { surface }\end{array}$ & $\begin{array}{l}\text { Cut and } \\
\text { wound }\end{array}$ & $\begin{array}{l}\text { Bark powder of stem applied } \\
\text { externally }\end{array}$ \\
\hline \multirow[t]{3}{*}{$\begin{array}{l}\text { Mikania cordata (Burm. f.) } \\
\text { Rob., Asteraceae, Z- } 78\end{array}$} & Assamilata & Leaves & $\begin{array}{l}\text { Cut and } \\
\text { wound }\end{array}$ & Leaf paste applied externally \\
\hline & & & Diarrhoea & Leaf juice taken internally \\
\hline & & & Gastrict pain & Leaf juice taken internally \\
\hline $\begin{array}{l}\text { Mimosa pudica L. } \\
\text { Mimosaceae, Z- } 80\end{array}$ & Laizzabati & Roots & Diarrhoea & Root juice taken internally \\
\hline $\begin{array}{l}\text { Ocimum sanctum L. } \\
\text { Lamiaceae, Z- } 288\end{array}$ & Tulsi & Leaves & $\begin{array}{l}\text { Cold and } \\
\text { cough }\end{array}$ & Leaf juice taken internally \\
\hline $\begin{array}{l}\text { Oroxylum indicum (L.) Kurz } \\
\text { Bignoniaceae, Z- } 431\end{array}$ & Thona & $\begin{array}{l}\text { Bark, } \\
\text { Leaves, } \\
\text { Flowers }\end{array}$ & Jaundice & $\begin{array}{l}\text { Taken bark juice and fried } \\
\text { leaves and flowers internally }\end{array}$ \\
\hline $\begin{array}{l}\text { Paedaria foetida L. } \\
\text { Rubiaceae, Z- } 1116\end{array}$ & Gandhaveduli & Leaves & Diarrhoea & Leaf juice taken internally \\
\hline $\begin{array}{l}\text { Persicaria hydropiper ( L.) } \\
\text { Spach. Polygonaceae, Z- } 772\end{array}$ & Bishkatali & Leaves & Jaundice & Leaf juice taken internally \\
\hline $\begin{array}{l}\text { Phyllanthus emblica L. } \\
\text { Euphorbiaceae, Z-369 }\end{array}$ & Amloki & Fruits & $\begin{array}{l}\text { Fever and } \\
\text { Malaria }\end{array}$ & Ripe fruits taken internally \\
\hline $\begin{array}{l}\text { Scoparia dulcis L. } \\
\text { Scrophulariaceae, Z-347 }\end{array}$ & Bondhania & Leaves & Diarrhoea & Leaf juice taken internally \\
\hline
\end{tabular}


Table 1 Contd.)

\begin{tabular}{|c|c|c|c|c|}
\hline $\begin{array}{l}\text { Smilax macrophylla Roxb. } \\
\text { Smilacaceae, Z-1029 }\end{array}$ & Kumarilata & $\begin{array}{l}\text { Shoot } \\
\text { apex }\end{array}$ & Impotence & Shoot apex taken internally \\
\hline \multirow{3}{*}{$\begin{array}{l}\text { Stephania japonica (Thunb.) } \\
\text { Miers, Menispermaceae Z-315 }\end{array}$} & Muchchanilata & Leaves & Diarrhoea & Leaf juice taken internally \\
\hline & & & $\begin{array}{l}\text { Cut and } \\
\text { wound }\end{array}$ & Leaf paste applied externally \\
\hline & & & Jaundice & Leaf paste taken internally \\
\hline \multirow{3}{*}{$\begin{array}{l}\text { Sterculia villosa Roxb. ex } \\
\text { Smith, Sterculiaceae, Z-135 }\end{array}$} & Udal & Petiole & Diarrhoea & Petiole juice taken internally \\
\hline & & & Gastrict pain & Petiole juice taken internally \\
\hline & & & Impotence & Petiole juice taken internally \\
\hline \multirow{3}{*}{$\begin{array}{l}\text { Terminalia arjuna (Roxb. ex } \\
\text { DC.) Wight \& Arn. } \\
\text { Combretaceae, Z-47 }\end{array}$} & Arjun & Bark & Diabetes & Bark juice taken internally \\
\hline & & & Gastrict pain & Bark juice taken internally \\
\hline & & & Impotence & Bark juice taken internally \\
\hline $\begin{array}{l}\text { T. bellirica (Gaertn.) Roxb. } \\
\text { Combretaceae, Z-169 }\end{array}$ & Bohera & Fruits & $\begin{array}{l}\text { Fever and } \\
\text { malaria }\end{array}$ & Ripe fruits taken internally \\
\hline \multirow[t]{2}{*}{$\begin{array}{l}\text { T. chebula Retz. } \\
\text { Combretaceae, Z- } 403\end{array}$} & Horitaki & Fruits & $\begin{array}{l}\text { Fever and } \\
\text { malaria }\end{array}$ & Ripe fruits taken internally \\
\hline & & & Jaundice & Ripe fruits taken internally \\
\hline $\begin{array}{l}\text { Tinospora cordifolia (Willd.) } \\
\text { Hook. f. \& Thoms. } \\
\text { Menispermaceae, Z-1071 }\end{array}$ & Padmaguruz & Stem & Anthelmintic & Stem juice taken internally \\
\hline
\end{tabular}

FIC values were determined to know the agreement among the informants of Kalenga forest area for use of plants to treat certain ailment categories. The FIC values are presented in the Table 2. It is clear that the FIC values varied from 0.50 up to 0.95 with an average value of 0.73 . Dysentery has the highest FIC value 0.95 with 40 use-reports for 3 plant species. The species responsible for this high consensus was Litsea glutinosa with 40 of the 42 reported events, followed by impotence (FIC $=0.89$; 30 use-reports, 4 species), Cold and Cough (FIC $=0.86 ; 16$ use-reports, 3 species), Malarial fever ( $\mathrm{FIC}=0.85$, 35 use reports, 6 species). Medicinal plants supposed to be efficient in treating particular ailment have high FIC values. The high FIC value for dysentery possibly showed that this ailment is common in the study area due to poor sanitation in the region and there is a better communication established among informants for treating this ailment category. High FIC values also indicate that the species traditionally used to treat these ailments are worth searching for bioactive compounds. The least agreement $(\mathrm{FIC}=0.50)$ between the informants was observed for plants used to cure jaundice and as anthelmintic. The low FIC value as recorded in our study could be due to a lack of communication among people in different areas.

To determine culturally important medicinal species in the society, Fidelity Level (FL) of plants has been calculated based on use reports which have been cited by ten or more informants for being used against a given ailment. The FL values are presented in Table 3. The analysis showed that the highest FL value found in Litsea glutinosa followed by Andrographis paniculata, 
Oroxylum indicum, Mikania cordata, Glycosmis pentaphylla, Cajanus cajan and Chromolaena odorata. The least FL values were found in the cases of Justicia adhatoda and Paedaria foetida. FIC and FL analyses showed that the most commonly used species in the study area is Litsea glutinosa (FIC $=0.95)$ with 40 use-reports and FL value $(95.23 \%)$. When selecting the most preferred plant species for each ailment category, we took the high Fidelity Level (\%) in each category of ailment.

Table 2. Categories of ailments and informant consensus factor (FIC) for each category

\begin{tabular}{lccc}
\hline \multicolumn{1}{c}{ Use categories } & $\begin{array}{c}\text { Number of taxa } \\
\text { (Nt) }\end{array}$ & $\begin{array}{c}\text { Number of use report } \\
\text { (Nur) }\end{array}$ & $\begin{array}{c}\text { Consensus } \\
\text { factor }\end{array}$ \\
\hline Dysentery & 3 & 40 & 0.95 \\
Impotence & 4 & 30 & 0.89 \\
Cold and cough & 3 & 16 & 0.86 \\
Malarial fever & 6 & 35 & 0.85 \\
Diabetes & 2 & 8 & 0.85 \\
Gastric pain & 2 & 8 & 0.85 \\
Cut and wound & 7 & 29 & 0.78 \\
Diarrhoea & 8 & 25 & 0.70 \\
Allergy & 3 & 7 & 0.66 \\
Jaundice & 15 & 29 & 0.50 \\
Anthelmintic & 2 & 3 & 0.50 \\
\hline
\end{tabular}

Table 3. Most frequently used plants for different ailment categories based on highest FL (\%) in each ailment category (Total informants $=42)$.

\begin{tabular}{llcc}
\hline Botanical name & Ailment categories & $\begin{array}{c}\text { Citation for } \\
\text { particular disease } \\
\text { (use-report) }\end{array}$ & $\begin{array}{c}\text { Fidelity level } \\
\text { (\%) }\end{array}$ \\
\hline Litsea glutinosa & Dysentery & 40 & 95.23 \\
Andrographis paniculata & Malarial fever & 33 & 78.00 \\
Oroxylum indicum & Jaundice & 26 & 61.9 \\
Mikania cordata & Cut and wound & 25 & 59.52 \\
Glycomis pentaphylla & Jaundice & 17 & 40.47 \\
Cajanus cajan & Jaundice & 16 & 38.09 \\
Chromolaena odorata & Cut and wound & 15 & 35.71 \\
Justicia adhatoda & Cold and cough & 10 & 23.80 \\
Paedaria foetida & Diarrhoea & 10 & 23.80 \\
\hline
\end{tabular}

The present work is one of the initial afford to quantify the ethnomedicinal information in Bangladesh which provide better option for the selection of widely used medicinal plants for searching bioactive compounds to treat ailments. The study reported 35 medicinal plants with their uses from the Kalenga forest area. The efficacy and safety of all the reported ethnomedicinal plants need to be evaluated by phytochemical and pharmacological studies. Plants with high informant consensus factor, use report and fidelity level should be given priority to carry out bioassay and toxicity studies. From this study we suggest Litsea glutinosa for further ethnopharmacological studies, since this species has the high FIC and FL values. The results indicated that this species may be used for the development of new, cheap, effective, and eco- 
friendly herbal formulations for healthcare management (Cox and Balick,1994; Balick and Cox, 1997; Flaster,1996; Heinrich, et al.1998; Ghorbani, 2005; Khafagi and Dewedar, 2000). Further use of these herbal formulations for healthcare management will require safety and efficacy testing. According to forest villagers and our observations in the field, L. glutinosa is now a very rare plant in the forest area. Illegal and unsustainable collection of bark from this tree by the local crude drug traders is one of the major causes of depletion of this species from nature. There is an urgent need to formulate suitable conservation strategies for naturally growing ethnomedicinal plants to overcome their depletion from natural resources and to make these practices more ecofriendly.

\section{Acknowledgment}

The authors are grateful to all the informants of the research area for sharing their knowledge. Cooperation of Forest Department during filed study is duly acknowledged.

\section{References}

Ahmed, Z.U., Begum, Z.N.T., Hassan, M.A., Khondker, M., Kabir, S.M.H., Ahmad, M., Ahmed, A.T.A., Rahman, A.K.A. and Haque, E.U. (Eds) 2008a. Encyclopedia of Flora and Fauna of Bangladesh, Vol. 6. Angiosperms: Dicotyledons (Acanthaceae - Asteraceae). Asiatic Society of Bangladesh, Dhaka, pp. 1408.

Ahmed, Z.U., Hassan, M.A., Begum, Z.N.T., Khondker, M., Kabir, S.M.H., Ahmad, M., Ahmed, A.T.A., Rahman, A.K.A. and Haque, E.U. (Eds) 2008b. Encyclopedia of Flora and Fauna of Bangladesh, Vol. 12. Angiosperms: Monocotyledons (Orchidaceae - Zingiberaceae). Asiatic Society of Bangladesh, Dhaka, pp. 1-552.

Ahmed, Z.U., Hassan, M.A., Begum, Z.N.T., Khondker, M., Kabir, S.M.H., Ahmad, M., Ahmed, A.T.A., Rahman, A.K.A. and Haque, E.U. (Eds) 2009a. Encyclopedia of Flora and Fauna of Bangladesh, Vol. 7. Angiosperms: Dicotyledons (Balsaminaceae - Euphorbiaceae). Asiatic Society of Bangladesh, Dhaka, pp. 1-546.

Ahmed, Z.U., Hassan, M.A., Begum, Z.N.T., Khondker, M., Kabir, S.M.H., Ahmad, M., Ahmed, A.T.A., Rahman, A.K.A. and Haque, E.U. (Eds) 2009b. Encyclopedia of Flora and Fauna of Bangladesh, Vol. 8. Angiosperms: Dicotyledons (Fabaceae - Lythraceae). Asiatic Society of Bangladesh, Dhaka, pp. 1-478.

Ahmed, Z.U., Hassan, M.A., Begum, Z.N.T., Khondker, M., Kabir, S.M.H., Ahmad, M. and Ahmed, A.T.A. (Eds) 2009c. Encyclopedia of Flora and Fauna of Bangladesh, Vol. 9. Angiosperms: Dicotyledons (Magnoliaceae - Punicaceae). Asiatic Society of Bangladesh, Dhaka, pp. 1-488.

Ahmed, Z.U., Hassan, M.A., Begum, Z.N.T., Khondker, M., Kabir, S.M.H., Ahmad, M., and Ahmed, A.T.A. (Eds) 2009d. Encyclopedia of Flora and Fauna of Bangladesh, Vol. 10. Angiosperms: Dicotyledons (Ranunculaceae - Zygophyllaceae). Asiatic Society of Bangladesh, Dhaka, pp. 1-580.

Alexiades, M.N. 1996. Selected Guidelines for Ethnobotanical Research: A Field Manual. The New York Botanical Garden, New York, pp. 99-133.

Balick, M.J. and Cox, P.A. 1997. Ethnobotanical Research and Traditional Health Care in Developing Countries. In: Bodeker, G., Bhat, K.K.S., Burley, J. and Vantomme, P. (Eds), Medicinal Plants for Forest Conservation and Health Care. FAO, Rome, pp. 12-23.

Canalesa, M., Hernandez, T., Caballero, J., Vivor, A.R.D., Avila, G., Duran, A. and Lira, R. 2005. Informant consensus factor and antibacterial activity of the medicinal plants used by the people of San Rafael Coxcatlan, Puebla, Mexico. J. Ethnopharmacol. 97: 429-439.

Chambers, R. 1994. Participatory Rural Appraisal (PRA): Analysis of experience. World Development 22(9): 1253-1268. 
Cordell, G.A. 2000. Biodiversity and drugs discovery - a symbiotic relationship. Phytochemistry 55: 463468.

Cox, P.A. and Balick, M.J. 1994. The ethnobotanical approach to drug discovery. Scientific American 270: 60-65.

Firedman, J., Yaniv, Z. Dafni, A. Palewitch, D. 1986. A preliminary classification of healing potential plants, based on a rational analysis of an ethnopharmacological field survey among Bedouins in the Negev Desert. Israel. J. Ethnopharmacol. 16: 275-287.

Flaster, T. 1996. Ethnobotanical approach to drug discovery of bioactive compounds. Process in new crops. Proceedings of the Third Traditional Symposium, ASHS press, Alexandria, pp. 561-565.

Frei, B., Baltisberger, M., Sticher, O. and Heinrich, M. 1998. Medical ethnobotany of the Zapotecs of the Isthmus-Sierra (Oaxaca, Mexico): documentation and assessment of indigenous uses. J. Ethnopharmacol. 62: 149-165.

Ghorbani, A. 2005. Studies on pharmaceutical ethnobotany in the region of Turkmen Sahra, north of Iran (Part1): General results. J Ethnopharmacol. 102: 58-68.

Khafagi, I.K. and Dewedar, A. 2000. The efficiency of random versus ethno-directed research in the evaluation of Sinai medicinal plants for bioactive compounds. J. Ethnopharmacol. 71: 365-376.

Hassan, M.A. and Khan, M.S. 1986. Ethnobotanical record of Bangladesh - 1: Plants used for healing fractured bones. J. Asiatic Soc. Bangladesh (Sci.). 12(1\&2): 33-39.

Hassan, M.A. and Khan, M.S. 1996. Ethnobotanical record of Bangladesh - 2. Plants used for healing cuts and wounds. Bangladesh J. Plant Taxon. 3(2): 49-52.

Heinrich, M. 2000. Ethnobotany and its role in drug development. Phytotherapy Research 14: 479-488.

Heinrich, M., Ankli, A., Frei, B. and Weimann, C. 1998. Medicinal plants in Mexico: healers consensus and cultural importance. Social Science and Medicine 47: 1859-1871.

Hooker, J.D. 1872-1897. Flora of British India, Vols. 1-7. Bishen Singh Mahendra Pal Singh, Dehra Dun, India.

Hyland, B.P.M. 1972. A technique for collecting botanical specimens in rain forest. Flora Malesiana Bulletin 26: 2038-2040.

Khan, M.S., Hassan, M.A. and Uddin, M.Z. 2002. Ethnobotanical survey in Rema-Kalenga Wildlife Sanctuary (Habiganj) in Bangladesh. Bangladesh J. Plant Taxon. 9(1): 51-60.

Martin, G.J. 1995. Ethnobotany: A Methods Manual. Chapman \& Hall, London.

Mia, M.M.K. and Huq, A.M. 1988. A preliminary ethno-botanical survey in the Jointiapur, Tamabil and Jafflong area, Sylhet. Bangladesh National Herbarium Bulletin 3: 1-10.

Prain, D. 1903. Bengal Plants, Vols. 1-2 (Indian Reprints 1963). Botanical Survey of India, Calcutta.

Siddiqui K.U., Islam, M.A., Ahmed, Z.U., Begum, Z.T.N., Hassan, M.A., Khondker, M., Rahman, M. M., Kabir, S.M.H., Ahmad, M., Ahmed, A.T.A., Rahman, A.K.A. and Haque, E.U. (Eds), 2007. Encyclopedia of Flora and Fauna of Bangladesh, Vol. 11. Angiosperms; Monocotyledons. Asiatic Society of Bangladesh, Dhaka.

Teklehaymanot, T. and Giday, M. 2007. Ethnobotanical study of medicinal plants used by people in Zegie Peninsula, Northwestern Ethiopia. J. Ethnobiol. Ethnomed. 3: 1-11.

Trotter, R.T. and Logan, M.H. 1986. Informant census: A new approach for identifying potentially effective medicinal plants. In: Etkin, L.N. (Ed.), Plants in indigenous medicine and diet. Redgrave, Bedford Hill, New York, pp. 91-112.

Uddin, S.N. 2006. Traditional uses of ethnomedicinal plants of the Chittagong Hill Tracts. Bangladesh National Herbarium, Dhaka, 879 pp.

Uddin, M.Z. and Hassan, M.A. 2004. Flora of Rema-Kalenga Wildlife Sanctuary. IUCN Bangladesh Country Office, Dhaka, Bangladesh,120 pp.

Uddin, M.Z., Hassan, M.A., Rahman, M.M., and Arefin, M.K. 2012. Ethno-medico-botanical study in Lawachara National Park, Bangladesh. Bangladesh J. Bot. 41(1): 97-104. 
Uddin, M.Z., Roy, S., Hassan, M.A. and Rahman, M.M. 2008. Medicobotanical report on the Chakma people of Bangladesh. Bangladesh J. Plant Taxon. 15(1): 67-72.

Uddin, M.Z., Hassan M.A. and Khan, M.S. 2003. An annotated checklist of angiospermic flora of RemaKalenga wildlife sanctuary (Habiganj) in Bangladesh-11a. Magnoliopsida (Dicots). Bangladesh J. Plant Taxon. 10(1): 79-94.

Uddin, M.Z., Hassan, M.A. and Khan, M.S. 2002. An annotated checklist of angiospermic flora of RemaKalenga wildlife sanctuary (Habiganj) in Bangladesh-1. Liliopsida (Monocots). Bangladesh J. Plant Taxon. 9(2): 57-66.

Uddin, M.Z., Hassan, M.A. and Sultana, M. 2006. Ethnobotanical survey of medicinal plants in Phulbari Upazila of Dinajpur district, Bangladesh. Bangladesh J. Plant Taxon. 12(1): 63-68.

Uddin, S.N., Uddin, M.Z., Hassan, M.A. and Rahman, M.M. 2004. Preliminary ethno-medical plant survey in Khagrachari district, Bangladesh. Bangladesh J. Plant Taxon. 11(2): 39-48.

WHO 2001. World Health Organization traditional medicine strategy, 2002-2005. Geneva, pp. 1-52.

(Manuscript received on 27 January 2014; revised on 24 April 2014) 